\title{
Chapter 9 \\ Mediation and Conciliation in Collective \\ Labor Conflicts in the Netherlands
}

\author{
Katalien Bollen
}

\section{The Case ${ }^{1}$}

In organization Van der Zande, new pension plans need to be negotiated since the current arrangements cannot be prolonged on the same terms. The Works Council (WC) has withheld its consent to implement new arrangements since it is-according to them- a worsening of the existing regulation. In addition, the WC feels that it has been involved and informed too late, leading to some mistrust towards the employer. Parties decide and agree to go to the mediation office located at the Social Economic council, called the Joint Sectoral Committee. ${ }^{2}$

In order to prepare the mediation session at the Joint Sectoral Committee that will take place face-to-face, both the employer and the Works Council send their version of the facts to the Joint Sectoral Committee. During the face-to-face session, parties are asked to tell their side of the story. Special attention is paid to how parties communicate about and with each other. Clarifying questions are asked to explore underlying issues. In order to solve this matter, first the issues both parties agree on are identified, then communication

\footnotetext{
${ }^{1}$ This case is inspired by and adapted from a case submitted to the Joint Sectoral Committee for mediation.

${ }^{2}$ The Joint Sectoral Committees (JSC) are installed by the Social Economic Council (SER) at broad sectorial level and can be turned to in order to mediate a conflict or disagreement specifically between employer and the Works Council. Committee members are experts in employee participation rights and are familiar with the different sectors.
}

\section{K. Bollen (凶)}

Maastricht University, Tongersestraat 53, Maastricht 6211 LM, The Netherlands

e-mail: katalien.bollen@kuleuven.be; k.bollen@ maastrichtuniversity.nl

KU Leuven, Dekenstraat 2, 3000 Leuven, Belgium

(C) The Author(s) 2019

M. Euwema et al. (eds.), Mediation in Collective Labor Conflicts, Industrial Relations

\& Conflict Management, https://doi.org/10.1007/978-3-319-92531-8_9 
on the non-agreed parts is facilitated. Constant attention is paid to the way parties communicate and how they take decisions together, and members of the Committee intervene when this does not take place constructively.

After one long session of $5.5 \mathrm{~h},{ }^{3}$ both the employer and Works Council agree on the conditions for a new pension scheme, and have discussed the role of the $W C$ in the organization and how to collaborate in the future. After the session, emails are exchanged to come to a correct wording of the agreement, after which the agreement is implemented in practice.

\subsection{Introduction}

Collective conflicts may lead to high costs for organizations, employees and society at large. In the Netherlands, employers' and employees' organizations (the social partners) as well as government work together to shape national socio-economic policies at national, sectorial, and organizational levels (Nauta, 2015). The Dutch consultative economy represents a modus operandi whereby key stakeholder groups (unions, employer organizations, government, and other stakeholders), further their common interests through cooperation and negotiation. Together they seek for integrative agreements to maximize outcomes for all. This is also known as the Polder Model (a polder being an area of reclaimed land from the sea, typically found in the Netherlands), and has a long tradition.

The Netherlands is a country of great social peace with relative few collective labor conflicts (Van den Berg \& Van Rij, 2007). This is reflected in the low number of strikes, ${ }^{4}$ and days lost in strike (See Fig. 9.1), compared to the EU-25 average (Van der Velden, Dribbush, Lyddon, \& Vandaele, 2014). For example, on an annual basis barely 5.7 working days per year per 1000 employees are lost to collective actions in the Netherlands (period 2005-2009) compared to an average of 30.6 days in the EU-25. These figures are in line with the statistics of the Dutch Central Office of Statistics (CBS). Mostly, strikes are declared by the unions ( $>80 \%)$. In $70 \%$ of the cases, the unions were also involved in the negotiation that led to the end of the strike. One in three strikes relates to a Collective Labor Agreement (CLA) conflict, only $15 \%$ deals uniquely with a salary issue.

In sum, Dutch labor relations are perceived as rather harmonious. Dialogue and the interchange of ideas are preferred above strikes and confrontations. In this climate, social partners do not feel the need (yet) to introduce a permanent agency for settling collective employment disputes.

\footnotetext{
${ }^{3}$ On average parties have one face-to-face session of 2 hours by the JSC.

${ }^{4}$ See also more detailed information on https://www.etui.org/Services/Strikes-Map-of-Europe/ Netherlands.
} 


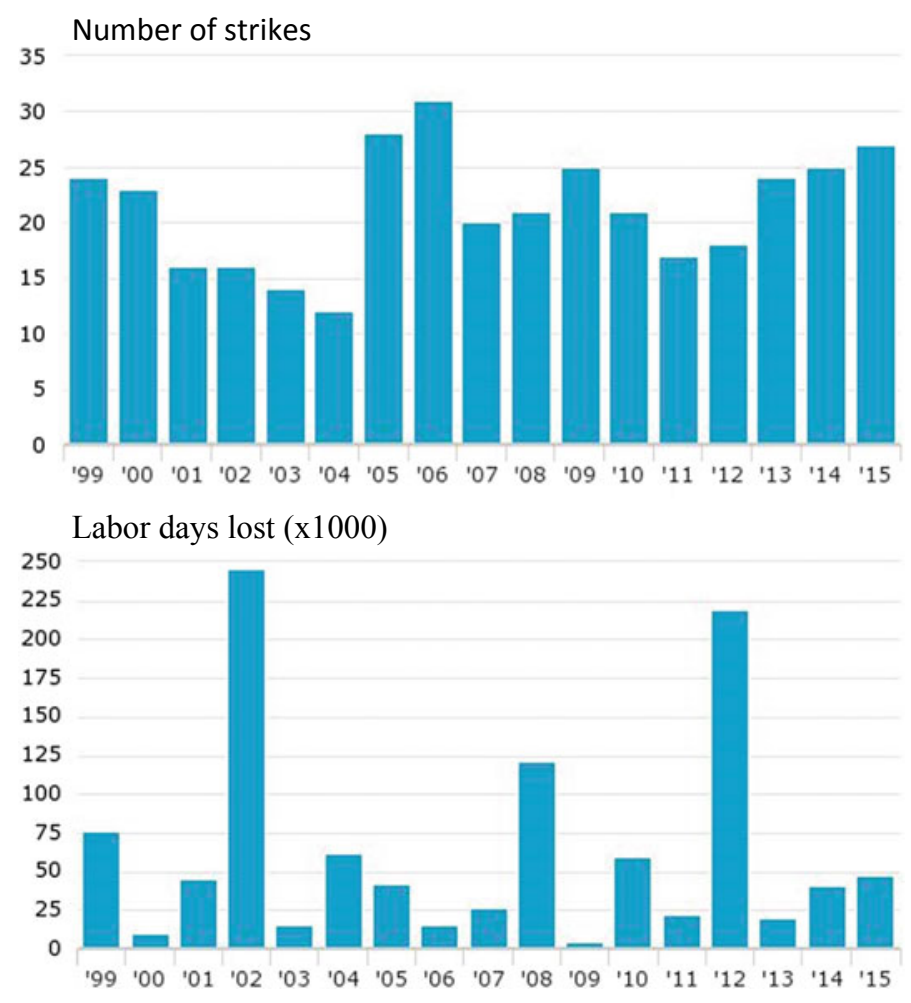

Fig. 9.1 The amount of strikes and lost labor days in the Netherlands (1999-2015)

In the Netherlands there has been a strong decline in union membership over the past 30 years as well as reduction of strikes and social actions (Brown, 2014). Looking at union membership, we see until 1980 a percentage of 38 , to currently 20 (Ter Steege, van Groeningen, Kuijpers, \& van Cruchten, 2012). This overall decline is in line with the global trend where the role of unions shifts (Euwema, Munduate, Elgoibar, Pender, \& García, 2015).

The three most important union federations are the Federation of Netherlands Trade Unions (FNV), the National Federation of Christian Trade Unions in the Netherlands (CNV) and the Trade Union Federation for Professionals (VCP). Although relatively few employees belong to a union, more than $80 \%$ of employees are covered by one of the 1100 Collective Labour Agreements (CLA's) in force (www.ser.nl). Agreements reached between an employers' organization and a union automatically apply to all employees working in the particular organization under this CLA. Organizations also have the right to negotiate a CLA directly with their 
own employees, without unions as intermediate. Typically this is done with the works council, being the local elected employee representation. ${ }^{5}$

Most Dutch employers (about 80\%) belong to a sector-based organization that represents their interests. This percentage is far above the EU average of 55\%. About 150 sector organizations affiliate to the federation VNO-NCW, the Confederation of Netherlands Industry and Employers, representing mostly larger companies. The general employers' association (AWVN) is a partner of VNO-NCW and is involved in the making of over 450 Collective Labor Agreements, mostly at midsize level. MKBNederland (the Royal Dutch Association of Small and Medium-sized Enterprises) represents small and medium-sized enterprises (employing up to 250 people).

\subsection{Characteristics of the Dutch System for Collective Conflict Management}

To understand the regulation of collective labor conflicts in the Netherlands, it is important to recognize the crucial role of social dialogue at an organizational level. Elected employee representatives in Works Councils (WCs) have a key legal position when it comes to organizational decision making. These representatives often are, but do not have to be unionized. Works Councils in the private sector and codetermination Councils in the public sector regularly face conflictive issues with top management. We differentiate in this chapter therefore between two types of collective conflicts involving a group of workers each with its own regulations and legal frameworks: conflicts between management and unions on the one hand and, management and $\mathrm{C}$ or co-determination councils on the other hand.

At the national level, there are two structures of consultation between social partners (employer organizations, trade unions, government). The Social and Economic council (SER) ${ }^{6}$ advises the Dutch government independently on a broad socialeconomic spectrum. The Labour Foundation (STAR) ${ }^{7}$ makes recommendations to trade unions and employer organizations with regard to the working conditions within companies and sectors.

At sector level, professional negotiators representing respectively employees and employers in a sector or organization negotiate CLA's (Huiskamp, 2003). Occasionally, the intervention by mediators is included in dispute settlement clauses in CLA's. It is estimated that $25 \%$ of the CLA's provide for dispute resolution clauses (de Roo, 2002).

\footnotetext{
${ }^{5}$ The role of the works council in CLA agreements is still under debate, however it is legal in the Netherlands for employers to directly make agreements with the works council. http://metamorfase. nl/uploads/Mag-een-OR-cao-afspraken-maken-2.pdf.

${ }^{6}$ SER, Sociaal-Economische Raad.

${ }^{7}$ STAR, STichting van de ARbeid.
} 


\subsubsection{Conflict Between Employer and Unions}

Employers' organizations and trade unions are inclined to adopt a strategy of conflict avoidance. This may also explain the absence of permanent dispute settlement machinery (Jagtenberg \& de Roo, 2002). Different to countries such as Belgium and the United Kingdom, the Netherlands have no central institute, statutory organization, or group of people appointed to mediate in collective conflicts between unions and employer(s). Informally, people often turn to a selected group of third parties, mostly experts such as academics or political and societal leaders to intervene as counsellor, scout, mediator or informer. Often these people are experts in the field of economics, finance, law or sociology. Usually these third parties are involved in a relatively late stage of the conflict.

Although the right to strike is positively confirmed by the courts in the Netherlands, there is no specific law regulating strikes. Instead it follows the European Social Charter (ESH, article 6 (4)) on this matter. According to this article, collective actions (including strikes) are allowed in case of conflicts of interest referring to disputes that are subject of collective negotiations and bargaining between employers and employees (e.g., wage increases, new CLA, social plan). There are three rules that need to be taken into account here (a) the timely announcement of a strike, (b) interests of employer and third parties need to be taken into account weighted, and (c) a strike must be the last resort. An employer who is informed, can take measures to prevent the strike or to limit its consequences. A strike is not justified when it goes against legal rules, endangers public order, national security or public health, when a solution can be reached through legal proceedings or manifest disproportion exists between the aim and social consequences of the action.

In the public sector, the Advisory and Arbitration Committee for the National Office (AAC, www.caop.nl) was established to assist the government authorities and civil servant unions in their role as negotiators (Akkermans, 1994). AAC advises or engages in arbitration or mediation to solve disputes that arise from the consultations between employers and employees.

Local entities like municipalities can turn to LAAC (Local Advisory and Arbitration Committee) when they have a conflict. These procedures are only used as last resort and rarely relied upon. Third parties active both in the public and private field, indicate that conflicts in the public sector are often more difficult to solve than the ones in the private sector, since the focus in the public sector is more on power and rights, and less on the underlying interests.

\subsubsection{Conflict Between Employer and WC}

At the level of the organization, we look at conflicts between the employer (CEO and/or HR director) and the Works Council (WC) or co-determination council (Euwema et al., 2015; Nauta, 2015). The $W C$ represents the interests of the staff 
in a company. It consults with management and the employer on the general organizational strategy, employment conditions and matters that have not been settled in the CLA (yet) and impact employee matters. In addition to advisory rights, the Works Council has also the right of consent. The latter implies that the employer may not implement a decision as long as the Works Council has not given its approval or the subdistrict court has given substitute approval to a proposed decision (Hofstee, 2018). The Works Councils Act ${ }^{8}$ stipulates that employees in organizations with 50 or more employees have a right to form a WC. Works Council members are paid by the employer and are often a union member. Around $70 \%$ of the companies in the Netherlands are obliged to have a WC and of those obliged, $67 \%$ has a WC in reality (Wajon \& Vlug, 2017). Small companies with less than 50 employees may set up a staff representative committee.

On request, WC's can hire expertise on various levels such as legal expertise, communication skills or mediation. In case of (a potential) conflict between WC and top management, parties may turn to the Joint Sectoral Committees as installed by the Social Economic Counsil (SER). In 2010, 23 joint sectoral committees in the market sector were restructured and reduced to 2 committees, Market I (commercial market sector) and Market II (non-profit sector referring to the former committees of healthcare, as well as the social and cultural sector). These two committees consist of 12 members and 12 substitute members and are located at the SER. The committee members are experts in employee participation rights and are familiar with the different sectors. A third joint sectoral committee is dedicated to government institutions and located at the CAOP, Centre for Labor Relations for Civil Servants. ${ }^{9}$ CAOP is the largest knowledge and service centre with regard to labour relations within the public domain. It advises and supports various sectors, including the Dutch government, as well as education and health care sector. CAOP is an independent foundation under the supervision of the social partners, and also offers mediation services for individual labor conflicts. The Works Councils Act (WOR) stipulates that the tasks of these committees are (a) to settle disputes between WC (also other employee participation bodies) and top management; (b) to register the agreements of WCs; (c) to answer questions from WCs and top management about employee participation; (d) to give information about the Works Councils Act and to encourage employee participation in general.

In 2013, The Works Council Act has been revised. Till then, parties were obliged to consult Joint Sectoral Committees when they planned to go to the Enterprise Chamber (of the Amsterdam Court of Appeal). This is no longer required. Currently, parties can opt to consult voluntarily and without any cost the Joint Sectoral Committees. While earlier the committees focused primarily on giving legal advice, since 2013 the Committees in the market sectors focus on mediation and conciliation. Legal advice can still be given on request of the conflict parties. Parties may also turn immediately to the subdistrict court judge or the Enterprise Chamber. Often, these committees

\footnotetext{
${ }^{8}$ Referred to in the Netherlands as WOR, Wet op Ondernemingsraden.

${ }^{9}$ Referred to in the Netherlands as Centrum Arbeidsverhoudingen Overheidspersoneel (CAOP).
} 
advise or mediate in the event of disagreements between employer and the WC about compliance with the provisions of the WOR. This often concerns issues related to the right of advise and consent, but it can also concerns conflicts in which a breach of trust plays a role, or when a party has the impression of not being listened to. For example in case of a reorganization: while the WC wants to be informed on the concrete next steps in the reorganization and the employee consequences, the employer prefers to wait and to decide later on whether to involve and consult the WC. This may give rise to feelings of distrust and not being listened to and the suspicion that the reorganization will be executed without consultation from the WC.

The joint sectoral committees are rarely consulted. Until 2013, the Committees handled 50-60 cases per year. Specifically, in 2011, 2012 and 2013, the committees of Market I and Market II receives 60, 67 and 49 mediation requests respectively. In 2014, 2015, 2016 and 2017 this fell to 22, 16, 24 and 14 mediation requests respectively, with an average number of 20 cases per year. Research by the SER $(2016)^{10}$ among Works Councils shows that when confronted with conflict, only $11 \%$ opts to consult the Joint Sectoral Committees. In the vast majority of the cases, WCs seek for external advice (outside the organization) from lawyers, consultants specialized in social dialogue, trainers or educational institutions, when the conflict has reached a high level of escalation, while unions are turned to less.

\subsection{Characteristics of the Mediators or Facilitators and the Third Party Procedures}

In 1923, the Dutch government introduced the Rijksbemiddelaar (Governmental Mediator) to mediate in collective conflicts. As mediators they operated alone and often took the initiative to intervene in a collective conflict. This type of mediator disappeared quickly once employers and unions developed regular consultation schemes, and a more constructive negotiation climate appeared.

Apart from the joint sectoral committees mentioned earlier, there are no formal institutions that mediate in collective conflicts, nor specific regulations for mediation in collective conflicts. No civil servants are appointed by the government working as conciliator or mediator. This implies that potentially everyone can act in such a capacity. Consequently, a large variety of potential third parties are active which makes it difficult to describe third parties characteristics intervening in collective conflict or to trace back the amount of mediations in collective conflicts.

In case of conflicts between employer and unions, parties can freely choose a mediator. The only prerequisite is that both parties agree upon the mediator. Particularly in the event of strikes with a major impact, ad hoc mediators are appointed by the parties. Often these mediations take place against the background of court injunctions. The ad hoc mediators are mostly well known public figures and are turned to because of their reputation, status, position (usually politicians or labor law univer-

\footnotetext{
${ }^{10}$ https://www.bedrijfscommissie.nl/publicaties/jaarverslagen.aspx.
} 
sity professors), their previous experience with similar cases, or their personality. Common denominators of these people are that they are perceived as experts, have a lot of experience and are respected by both parties. These conciliators or mediators are typically not affiliated with professional mediation associations. In fact, a limited number of people are asked to mediate regularly. An extra challenge for the this type of mediators is how to deal with the outside pressure of media.

In conflicts where employees are represented by the Works Council, various people with a different background are involved as third party, depending on the stage of the conflict (see Chap. 1 of this handbook). In Phase 1 (latent conflict) coaches, advisors and trainers for social dialogue offer training and advice. In Phase 2 (early stage conflict) legal counsellors, and trainers are asked to give primarily legal advice or to intervene informally. Third parties active in Phase 1 and 2 often engage in some way of preventive mediation in the sense that they promote constructive dialogue among the social partners. But they do not call themselves mediators or conciliators, nor are they perceived in this way by the parties. In Phase 3 (confrontation and escalation) parties generally turn to legal counsellors or union specialists. In Phase 4 (hot conflict), parties turn to judges, arbitration or court (e.g., Enterprise Chamber). Mediations by the Joint Sectoral Committees usually take place between Phase 3 and 4. Phase 5 refers to the restoration of the relationship and how to rebuild trust in each other. Interventions on this level are hardly seen. Consultant: "Parties just contact us with an ad hoc question to intervene. As such we help to extinguish or limit the fire. I do not know what happens next ... It would be a good idea to contact parties afterwards also to double check the effectiveness of the intervention."

Only a very few people acting as a mediator in collective conflicts have followed a course to become a mediator and most are not registered in the national register of the MfN. ${ }^{11}$ Judge: "When acting as a mediator in collective conflicts, you do not need a specific mediation training. You need experience in the field, possess a great deal of creativity, the ability to think out-of-the-box and possess a healthy portion of curiosity."

\subsection{Description of the Facilitation and/or Mediation Process by the Joint Sectoral Committee}

When a politician, judge or university professor is involved as a third party in a collective conflict, parties often expect a more evaluative approach (Who is right; What is the advice?). This will typically include a period of investigation, to understand the broader story behind the legal question. When a consultant in social dialogue, trainer or coach is asked, a more transformative or facilitative approach is expected (with

\footnotetext{
${ }^{11}$ In the Netherlands, the MfN register (Mediators Federation Netherlands) acts as the independent quality dome for mediation in the Netherlands. MfN registered mediators have completed a MfN accredited mediation training and keep their knowledge and skills continuously up to date (lifelong learning and permanent education) to keep their registration.
} 
focus to restore or improve the relationship). Many of these third parties indicate that they engage in separate conversations with parties before the joint face-to-face $\operatorname{session}(\mathrm{s})$.

When external third parties are hired by the WC, the fees are usually paid by the employer. Mediation by the Joint Sectoral Committee is free of charge. The only prerequisite for the mediation to take place is that both parties agree to mediate. A substantial part of cases presented to the Joint Sectoral Committees are withdrawn since parties engage again in conversations and negotiations before the joint session takes place.

The mediation style of the Joint Sectoral Committees representing the Market is facilitative. This is different from the 20th century where mediation was more evaluative and took the form of hearing parties and giving them a non-binding legal advice. This advice is necessary to go to the Enterprise Chamber (of the Amsterdam Court of Appeal). In Joint Sectoral Committees of the public sector, the primary focus is still on legal advice. Here parties are asked to present their case while the committee will ask questions. Parties only get an advice once they are back at work, not immediately in the session itself.

A typical mediation procedure at the Joint Sectoral Committees in the market sector consists of following steps: Before the face-to-face session in The Hague, parties are asked to provide the Committee and the other party with a description of the problem and the question(s) they have. The Committee represents the social partners and consists of 1 employer representative, 1 employee representative and 1 neutral member. In order to prepare the meeting, committee members read the documents, discuss the case with each other, look for interdependencies and formulate questions for the face-to-face session. In case something is unclear, parties are asked for additional information. The typical time lag between a request for mediation and the face-to-face meeting is 2 months. The face-to-face meeting in The Hague usually takes one hour and a half to 2 hours. Although parties regularly are accompanied by legal counsellors, the conflict parties themselves are asked to describe the problem and to formulate their questions. Member Joint Sectoral Committee: "We try to banish legal advisors. From the moment they step into the room, the atmosphere changes completely, with little room to communicate constructively. Our main focus is on the underlying problems and needs. And often, these cannot be found in legal documents. You can only discover the root of the problem by talking to people involved in and impacted by the conflict."

At the start of a session a member of the Committee explains the procedure in order to manage the expectations. Typical interventions are active listening, asking questions to identify underlying issues and problems, describing what they see (metacommunication) and trying to empower people. Committee Member: 'Describing what you see as third party is very important. It helps parties to identify what is often too difficult for them to say. Specific (technical) knowledge is not that important. A reoccurring theme is how to deal with mistrust. This is often the bottleneck in collective conflicts between WC and top management.' A caucus (one to one meeting between the parties and the committee) may be an option when emotions run high or parties do not seem to be willing to tell the full story to the conflict. The sector committees 
of the Market only rarely make use of caucus. The main aim of the Joint Sectoral Committee is to stimulate parties to find a solution together. Member Joint Sectoral Committee: "It is our intention to empower people to find their own power again. When involved in conflict they have drifted away, not only from each other, but also from their selves".

If the Joint Sectoral Committee fails in facilitating the conflict at hand, the committee issues an advisory opinion that is not binding, neither for the parties, nor for the courts. Typically, there is only 1 face-to-face session. As such this can be seen as a very speedy procedure that offers to both parties the opportunity to clarify their side of the story. When the committee assumes that the question presented is part of a bigger issue which cannot be sufficiently solved in the session, they may refer to further mediation by a mediator, consultant or coach. There is no formal list however for potential mediators or coaches parties can turn too. After the session took place, parties are send a form to evaluate the intervention.

In urgent cases, parties can ask for an emergency procedure in order to limit the time between the request for mediation and the face-to-face session. This procedure is only rarely used.

If the dispute concerns matters as listed in Article 26 of the WOR, one can decide to go directly to the Enterprise Chamber in Amsterdam. In this case, it concerns a decision by an employer whereby (a) the employer wrongly did not request advice from the WC, (b) the employer asked advice from the WC at such a late time that the advice has no influence on the decision, (c) the decision of the employer is not in accordance with the advice of the WC or, (d) the advice of the WC has been followed but some new facts have become known and that if the WC had known them this would have led to a different opnion. If one goes to the Enterprise Chamber, the focus is on the legal aspect of the case. Nevertheless, members of the Enterprise Chamber indicate that WCs regularly consult the Enterprise Chamber not solely for judicial reasons. "In general, WCs engage in these legal actions because of other reasons than only the judicial ones. By going to the Enterprise Chamber they want to show "I do not accept this treatment any longer. Now it is over." So the underlying topic is: "I want to be listened to and treated in a respectful way." This is an important aspect to work on since we deal with continuous relationships." Sessions at the Enterprise Chamber take usually between 2 and 5 hours. When issues appear that relate to interpersonal relations, judges of the Enterprise Chamber may refer to mediation. The judge can also refer to, or appoint, a specific mediator when asked for by the conflicting parties.

In general, there are very few rules that guide conciliation or mediation in collective labor conflicts. A common denominator is that third parties stress the great importance of tailor-made interventions, active listening and questioning to identify underlying problems and empathy. Member of Joint Sectoral Committee: "It is crucial to design tailor-made interventions and to show empathy. You need to make sure that parties can walk out the room with their heads up high. Only this will make some room for long term solutions of the conflict." 


\subsection{Effectiveness the Dutch System for Collective Conflicts and Suggestions for Improvement}

Different stakeholders indicate that the system for collective conflict management works quite well. At the same time, they all agree that conflicts too often stay 'hidden' until they explode or escalate. An explanation for this could be that the Netherlands is known for its 'polderen' which puts emphasis on the idea of interchange, compromise and cooperation. To admit that you have a conflict, is often seen as a blame. Trainer: 'We see that many people think they should be able to solve the conflict themselves. And they try to do so as long as possible. Asking advise or turning to third parties is often seen as a loss of face and this is why parties usually wait a long time to turn to a third party.' Another reason could be that parties are afraid of the costs and time related to a legal procedure. Consequently, people muddle through often resulting in deadlock situations. In these cases, the (initial) conflict on the content has usually transformed into a relational conflict. Employee representative: "Now the word conflict is often synonym for war and thus stays unspoken. We need to learn how to disagree constructively." A third reason refers to the fact that the primary parties do not know that they can invite a mediator and/or where to find a third party.

Different parties involved in the research (employers, employees, WCs, unions, members Joint Sectoral Committees, Enterprise Chamber, etc.) suggest points for improvement which may address the difficulties parties encounter when confronted with collective conflicts.

1. Clarify the role of mediation, mediators and where to find them

Although the Dutch government is in favour of mediation, no special agreements have been reached by the social partners on the use of Alternative Dispute Resolution in collective labor conflicts. Often conflicting parties are not familiar with mediation, and are not well informed about the use of mediation. Member WC: "To be honest, it is not clear to me (and I guess also to other stakeholders) how mediation can contribute to my particular case. I did not know we can hire mediators ... I assumed we could only hire legal advice". This is remarkable since the WOR stipulates that the WC can invite an external consultant to give training or advise on several topics including social processes, such as communication and conflict. If people are willing to turn to a mediator, they often do not know where to find a good, qualified mediator that can be trusted, and is knowledgeable about the WOR. Consequently parties do not engage in this "risky" business. In the field there is a high need for more information. As an employer representative formulates it: "There should be a trusted source that helps us to find the right people at the right moment, including mediation. A flow chart explaining who could be contacted when, with some exemplary questions would be very helpful." The most natural party to take up this role might be the SER. Some unions already invest in mediation (behind de scenes), but indicate it is difficult to integrate the mediator role and the need for showing muscles when representing people which makes it difficult to make some compromises. Third parties in the field 
that are confronted with (potential) conflict need to be trained on how to analyse the problem and to see whether mediation could be of added value to get to a solution.

\section{Clarify the role of the Joint Sectoral Committees}

Currently, perceptions and expectations on the joint sectoral commissions are diffuse. Many stakeholders still assume that Joint Sectoral Committees give legal advice and engage in arbitration, which is currently not the case. The Committees should be more clear on what they offer and the SER could strengthen its role in the field. Employer representative: "The SER should profile itself as an expertise center in collective conflicts both in theory and practice. This implies strengthening and broadening its current role." For instance, the fact that the secretary of the SER gives advice on how to deal with a difficult situation or conflict is unknown to most parties. Now, works councils regularly hesitate to turn to the Joint Sectoral Committees as they are afraid how their employer will react when finding out employees turned to a Joint Sectoral Committee, or they believe the employer will ignore the agreements made during the session. Another suggestion is to make a mediation session obligatory when a mediation request is made by one of the parties. Member WC: "Currently, parties still have the option to decline participation in mediation. This is a pity. For aWC it might be really difficult to get hold of the employer or the top management. If there is no other way to push them to the table, the only option is to go to court. In my opinion, parties lose in this way many opportunities to have a decent talk" (Here you can find a short movie that illustrates the mediation process as it takes place in the Committees for the Market Sector https://www.bedrijfscommissue.nl/).

3. More attention for preventive measures and care after the intervention

The law on WCs in the Netherlands made provisions for the investment in training for WCs. Every year the SER draws up targets amounts for the training of the WC. Members of the WC are entitled to training. The employer is obliged to offer members of the WC the opportunity to receive training of sufficient quality for a number of days per year during working hours while keeping pay as they deem necessary for the fulfillment of their duties. Since the reform of this law in 2013, WCs have to claim budget from the employer. One of the consequences is that people tend to follow less courses or training. This is especially the case in smaller organizations. Union representative: "Before the reform of the WOR law, we provided three full days of training. Now we provide a half day training with a focus on the legal aspects. All training on the level of social skills has been removed." Currently, there is a need for more training on social skills both on the level of how to communicate constructively with each other, but also the employer, and how to function as a group (Works Council). This can be seen as preventive mediation. If one knows well his role, as well as how to communicate constructively, this may prevent future problems and conflicts. In these trainings, it would be good to involve on a very regular base the employer or top management. Member Joint Sectoral Committee: "In many cases, a re-occurring theme is the lack of trust and respect which affects communication in a very negative way. There is much room for preventive measures. People need to learn 
how to communicate, how to negotiate and how to reach out to each other in case of problems. They need time to exercise this on the work floor when things are not going wrong yet." Also, parties see room for improvement for the period after a conflict and direct intervention. Third parties are rarely asked to facilitate trust rebuilding, nor do they offer their service for this.

4. Invest time and money in participatory bodies like the Works Council

Both top management and employees need to understand the importance of a strong WC with a high level of knowledge and expertise (Nauta, 2015). In some cases top management tends to perceive the WC as a loss of time and money. More time needs to be invested in education to inform people (top management and HRM) on the role and benefits of a good, knowledgeable WC (management courses, HRM courses). Employers could also get coaching on this level. Currently, employers confronted with insecurities or uncertainties, tend to go to a lawyer. At the same time, Works Councils need to be trained in how to be constructive and critical towards their management. They also need to realize what position they can and want to have. The current decrease in training is a potential threat to the knowledge level and know-how of the WC.

\section{Control mechanisms}

Although the law provides in participatory bodies, there is no controlling institute that checks compliance with the rules regarding participatory bodies or what the effects are of going to the Joint Sectoral Committee or Enterprise Chamber on the working relationshipe between the employer and the WC. A good option would be to invest in an internal coordinator who controls this.

\section{Potential threats}

The law on WCs in the Netherlands (WOR) aims to offer a framework to improve constructive dialogue. In theory there is a strict division between 2 types of collective conflicts related to the parties involved: unions on the one hand, or the works council, representing the employees on the other hand. Each has its own responsibilities and legal position. In practice, this distinction is becoming less clear. Not only are many members of the WC trade union members, but there is also an increasing trend that issues that would be dealt with by the unions, end up at the level of the WC (e.g. CLA's closed with the works council). This is especially the case in companies with a low level of unionization. This puts a lot of pressure on the WC to solve complex issues, which they are possibly not up to.

\subsection{Conclusion}

The system for collective conflict management in the Netherlands including the crucial role of Works Councils, is unique. When investigating the role of mediation in 
collective labor conflicts, our results show that a formal system for mediating collective conflicts where the trade unions are involved (CLA related conflicts) is lacking. Parties tend to search in their own networks for mediators, or turn to well-known public figures because of their reputation, expertise, or position (usually politicians or labor law university professors). Although there are some provisions for mediation for the collective conflicts related to the Works Council (Joint Sectoral Committees), the role of mediation in collective conflicts is currently limited and should be increased next to more legal provisions.

Acknowledgements Hereby I want to thank sincerely all the interviewees who participated in the interviews as well as the organizations that facilitated the research and conference: SBI Formaat, SER, CAOP, SomZ.

\section{References}

Akkermans, M. J. W. M. (1994). Gelijk hebben en gelijk krijgen. AAC: Den Haag.

Brown, W. (2014). Third party processes in employment disputes. In: The Oxford handbook of conflict management in organizations (pp. 135-149).

de Roo, A. J. (2002). The settlement of collective labour disputes in the Netherlands. In Valdes Dal$\operatorname{Re}($ Ed.), Labour conciliation, mediation and arbitration in European Union countries. Madrid: Ministero de Trabajo y Asuntos Sociales.

Euwema, M., Munduate, L., Elgoibar, P., Pender, E., \& García, A. B. (Eds.). (2015). Promoting social dialogue in European organizations: Human resources management and constructive conflict management. Cham: Springer. https://doi.org/10.1007/978-3-319-08605-7_8.

Hofstee, L. I. (2018). WOR, Wet op de Ondernemingsraden 2018. Vakmedianet.

Huiskamp, R. (2003). Arbeidsrelaties en onderneming: Vernieuwing in theorie, empirie en praktijk. [Employment relations and enterprises: Renewal of theory, empirical results, and practice.] Utrecht: Lemma.

Jagtenberg, R. W., \& de Roo, A. J. (2002). Mediation in the Netherlands, National Report for the XVIth Congress of the International Academy of Comparative Law, Brisbane, July/August.

Nauta, A. (2015). Industrial relations and works councils in the Netherlands-Results from interviews and a survey among HR managers. In M. Euwema et al. (Eds.) Promoting social dialogue in European organizations (pp. 105-121), Industrial Relations \& Conflict Management 1. Cham: Springer. https://doi.org/10.1007/978-3-319-08605-7_8.

SER. (2016). Rapportage enquête omgaan met conflicten over medezeggenschap. https:// www.ser.nl/nl/ /media/files/internet/publicaties/overige/2010_2019/2016/omgaan-conflictenmedezeggenschap.ashx.

Ter Steege, D., van Groeningen, E., Kuijpers, R., \& van Cruchten, J. (2012). Vakbeweging en organisatiegraad van werknemers. [Trade union and union membership of employees.] Centraal Bureau van de Statistiek, Sociaal-Economische Trends, $4^{\mathrm{e}}$ kwartaal 2012. https://www.cbs.nl/ NR/rdonlyres/B93BC030-43CE-47A9-B819-DB88CBC9AF01/0/2012k4v4p9art.pdf.

Van den Berg, N., \& Van Rij, C. (2007). Ervaringen van werkgevers met de cao en avv. [Experiences of employers with the CLA and the Statement of General Applicability.] (publicatie nr. 1529). Amsterdam: Regioplan.

Van der Velden, S., Dribbush, H., Lyddon, D., \& Vandaele, K. (2014). Strikes around the world, 1968-2005: Case studies of 15 countries. Aksant Academic Publishers.

Visee, H., Saalbrink, S., \& Mevissen, J. (2012). Naleving van de wet op de ondernemingsraden. [Compliance to the law on works councils]. Amsterdam. 
Wajon, I., \& Vlug, P. (2017). Naleving van de Wet op de Ondernemingsraden: Stand van zaken begin 2017. Rotterdam: Numansdorp.

Open Access This chapter is licensed under the terms of the Creative Commons Attribution 4.0 International License (http://creativecommons.org/licenses/by/4.0/), which permits use, sharing, adaptation, distribution and reproduction in any medium or format, as long as you give appropriate credit to the original author(s) and the source, provide a link to the Creative Commons license and indicate if changes were made.

The images or other third party material in this chapter are included in the chapter's Creative Commons license, unless indicated otherwise in a credit line to the material. If material is not included in the chapter's Creative Commons license and your intended use is not permitted by statutory regulation or exceeds the permitted use, you will need to obtain permission directly from the copyright holder.

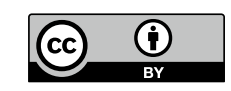

